\title{
IMPLEMENTÁCIA PROJEKTU KAAT- ZNALOSTNEJ ALIANCIE V LETECKEJ DOPRAVE - PRÍBEH ÚSPEŠNÉHO PROJEKTU
}

\section{IMPLEMENTATION OF THE KAAT PROJECT - KNOWLEDGE ALLIANCE IN AIR TRANSPORT - THE STORY OF A SUCCESSFUL PROJECT}

\author{
Alena Novák Sedláčková1 ${ }^{,}$Antonín Kazda ${ }^{1}$, Andrej Novák ${ }^{1 *}$
}

\begin{abstract}
Abstrakt Článok sa zoberá problematikou vysokoškolského vzdelávania v nadväznosti na potreby leteckého priemyslu ako odvetvia národného hospodárstva. V súvislosti s narastajúcou potrebou skvalitňovania a zefektívňovania procesu vzdelávania, je potrebné riešit’ medzinárodnú spoluprácu pri vzdelávaní odborníkov v leteckej doprave. Odpoved'ou na tento problém bolo vytvorenie znalostnej aliancie v rámci projektov ERASMUS+, ktorá analyzuje globálny trh povolaní a kvalifikácií v leteckej doprave. Ciel'om projektu bolo špecifikovat' zoznam súčasných povolaní, ale aj budúcich povolaní v nadväznosti na analýzu kvalifikácií v odvetví leteckej dopravy. Na základe týchto výstupov projektu bol vytvorený nový študijný program ako aj upravené programy d'alšieho vzdelávania v letectve. Príspevok poukazuje na výstupy a prínosy takejto spolupráce.
\end{abstract}

Klúčové slova celoživotné vzdelávanie, znalostné aliancie, vzdelávanie

Summary The paper is focused on the higher education system in relation to the needs of the aviation industry as a branch of the national economy. In connection with the growing need to improve and streamline the education process it is important to develop and create the international cooperation in education of professionals in aviation industry. The response on this problem was the creation of knowledge alliance supported by the ERASMUS+ project, which analysed the global market of occupations and qualifications in the air transport. Based on the results of qualification analyses a list of current occupations was specified, as well as future occupations in the aviation sector. On the project outputs a new study program was created and further lifelong learning programs were modified. The paper points to the outputs and benefits of this cooperation.

Keywords lifelong learning, knowledge alliances, education

\section{1 ÚVOD}

Projekt KAAT - Knowledge Alliance in Air Transport je ERASMUS+ projekt zameraný na znalostné aliancie (číslo projektu: 588060-EPP-1-2017-1-RO-EPPKA2-KA). Koordinátorom projektu je University Politehnica of Bucharest v Rumunsku. Do projektu sa zapojilo 17 partnerov (7 univerzít zo 6 krajín, 10 partnerov z priemyslu a 11 spolupracujúcich pridružených partnerov). Úloha priemyselných partnerov je nezastupitel'ná. Slúžia ako „zrkadlo“ úrovne univerzitného vzdelávania a programov odbornej prípravy v leteckej doprave a poskytujú vel’mi dôležitú spätnú väzbu z hl'adiska potrieb rôznych sektorov civilného letectva.

\footnotetext{
1 Žilinská univerzita v Žiline, fakulta PEDAS, KLD, Univerzitná 8215/1, 010 26, Žilina, Slovenská republika

${ }^{*}$ korespondenční autor, tel.: +421 415133 450, e-mail: andrej.novak@fpedas.uniza.sk
} 
Príprava projektu sa začala v roku 2015 v Bukurešti. Profesor Sorin Zaharia ako vedúci tohto projektu ho najskôr koncipoval ako rumunský národný projekt. V roku 2016 tím zodpovedný za prípravu projektu preniesol svoje skúsenosti a pripravil prvý projekt EÚ Erasmus +, ktorý však nebol schválený. Prof. Zaharia vložil do zlepšenia a prípravy značné úsilie a motivoval všetkých partnerov. Aktualizovaný projekt bol v roku 2017 úspešný. Na Slovensku boli v tom čase schválené iba dva projekty vedomostných aliancií. Dohoda o grante bola podpísaná v decembri 2017 a v januári 2018 bolo prvé zasadnutie riadiaceho výboru v Bukurešti.

\section{VÍZIA PROJEKTU}

Hlavným ciel'om projektu je vytvorenie znalostnej aliancie v leteckej doprave, čo je v dnešnom globálnom svete, najmä v oblasti vzdelávania v letectve pre úspešnost' jednotlivých podnikov rozhodujúce. V projekte je kl'účová prvá a druhá čast' projektu (Working Package - WP). WP1 a WP2 analyzujú globálny trh povolaní a potrebných kvalifikácií v letectve. Prvým krokom bolo špecifikovat' zoznam súčasných povolaní, ako aj budúcich povolaní v letectve.

\section{1 Analýza povolaní a kvalifikácií v letectve}

Vo WP1 definovali a popísali všetci riešitelia projektu viac ako 120 povolaní, kedy sa venovali aj budúcim novým povolaniam. Pre tieto povolania je potrebné navrhnút' vzdelávacie a školiace programy. Následne bola vo WP2 vypracovaná analýza kvalifikácií v odvetví leteckej dopravy. Akademici ako aj partneri z priemyslu identifikovali kl'účové kompetencie pre niekol'ko typov povolaní s víziou „inteligentnej kvalifikácie pre inteligentné povolanie“.

Pre synchronizáciu d’alšieho vzdelávania je potrebný kvalifikačný rámec, kedy každý štát si definuje národný kvalifikačný rámec (NKR)(Fondová et. al., 2013). Európsky kvalifikačný rámec (EQF) tvorí „premostenie“ medzi jednotlivými národnými systémami kvalifikácií. V projekte boli porovnané kvalifikačné rámce 6 krajín a následne bola uplatnená metodika pre sektorový kvalifikačný rámec pre leteckú dopravu (SQFAT). Identita SQFAT je popísaná 10 zložkami štruktúrovanými v 3 úrovniach (určujúce faktory a procesy rozvoja kvalifikácií, opis a uznávanie kvalifikácií a vplyv na proces odbornej prípravy na jednej strane a na sociálny rozvoj, inováciu a kvalitu života na strane druhej). SQFAT opisuje kvalifikácie zodpovedajúce štyrom kvalifikačným úrovniam EQF - vysokoškolské alebo nevysokoškolské kvalifikácie (EQF 5), bakalárske štúdium (EQF 6), magisterské štúdium (EQF 7) a doktorandské štúdium (EQF 8). Každá kvalifikácia je vymedzená prostredníctvom výsledkov vzdelávania vyjadrených z hl'adiska vedomostí, zručností, autonómie a zodpovednosti, sociálneho a osobného rozvoja súvisiaceho s každou úrovňou štúdia. Výskum bol zameraný na koncepčný základ pozostávajúci z klúčových pojmov: kategórie, kompetencie, typ a deskriptor spôsobilosti, koncepčno - metodický model na opis kvalifikácií v sektore leteckej dopravy v EÚ (SQFAT Matrix a Grid 1).

\section{2 Informačné technológie aplikované v letectve}

Na základe výsledkov analýz WP1 a WP2, ktoré boli schválené aj Európskou Komisiou, bol ako súčast’ WP3 (Koncepcia a implementácia nového inovatívneho študijného programu) vytvorený nový inovatívny študijný program s názvom „Informačné technológie aplikované v letectve“ („IT Applied in Aviation (ITAA))“. Pri návrhu jeho koncepcie spolupracovali všetci partneri. Hlavným ciel’om bolo vytvorit’ „tak dobrý študijný magisterský program ako sa len dá". Každá z partnerských univerzít bola pri tvorbe magisterského študijného programu zastúpená svojimi najkvalitnejšími pedagógmi - garantmi zodpovednými za tvorbu učebných plánov a učebných osnov pre každý predmet. Predsavzatím partnerov bolo akreditovat' tento študijný program vo svojich krajinách a pre tento projekt získat' sedem akreditácií študijného programu v rôznych štátoch EÚ. Z dôvodu legislatívnych obmedzení na začiatku projektu jeden z partnerov - lotyšský Transport and Telecommunication Institute opustil projekt mesiac po jeho začiatku. 
Od ministerstva školstva dostali rozhodnutie, že je úplne nemožné vytvorit’ a akreditovat' nový študijný program v Lotyšsku v čase, ked’ pripravujú Stratégiu na zníženie počtu existujúcich študijných programov.

Akreditačný proces je pre všetkých šest' partnerských univerzít výzvou. Namiesto jednotného európskeho legislatívneho rámca v oblasti vzdelávania a uznávania odbornej kvalifikácie v súlade so Smernicou Európskeho parlamentu a Rady 2005/36 / ES zo 7. septembra 2005, sú kritériá každého ministerstva školstva alebo akreditačného výboru síce podobné, ale vo viacerých bodoch sa zásadne líšia. Naviac je akreditačný proces časovo náročný a personálne podmienený. Každá univerzita tak začala svoju samostatnú, náročnú a zložitú cestu a verí v úspešne ukončený akreditačný proces.

\subsubsection{Slovenský príbeh}

Žilinská univerzita v Žiline (UNIZA) je aktívnym partnerom vo WP3 - Koncepcia a implementácia nového inovatívneho študijného programu „Informačné technológie aplikované v letectve -IT Applied in Aviation“. Na príklade WP3 je možné ilustrovat', ako politická situácia v krajine môže ovplyvnit' implementáciu projektu. Ak posudzujeme ciel' WP3 spätne z perspektívy januára 2018, ked' bol KAAT projekt schválený, tak v tom čase proces akreditácie nového študijného programu trval štandardne minimálne jeden rok. Slovenská Akreditačná komisia posudzovala študijné programy podl'a zákona č. 131/2002 Z. z. o vysokých školách v znení neskorších (d’alej označovaný ako vysokoškolský zákon). Všetky dokumenty síce museli byt' v slovenskej a anglickej verzii, ale v tej dobe nebolo v SR možné schválenie spoločného študijného programu, kde by boli garantmi predmetov učitelia zo 6 univerzít z 5 rôznych štátov EÚ. Víziou projektu bolo vytvorenie excelentného študijného programu nielen v štruktúre predmetov, ktoré boli konzultované aj s partnermi z priemyslu, ale aj vo forme výučby. Na všetkých šiestich univerzách mali študenti navštevovat' jeden študijný program - ITAA a zdiel'at' jeden spoločný rozvrh. Zároveň by zdiel'ali aj tých istých vyučujúcich. Harmonogram študentov by bol harmonizovaný. Učitel' zodpovedný v projekte za predmet mal vyučovat' na vlastnej univerzite a prostredníctvom videokonferencie aj študentov z ostatných 5 univerzít. Bolo na rozhodnutí učitel’a, či pripraví kurz ako kontaktnú výučbu („tvárou v tvár“), kurz podporovaný videokonferenciou alebo online kurz, ktorý by mohol predstavovat' takmer $30 \%$ z celkového objemu výučby.

V súčasnosti, počas krízy COVID 19 je online vyučovanie úplne bežné a nikoho neprekvapuje, ale pred dvomi rokmi bola situácia úplne iná. V tom čase bola takáto myšlienka na Slovensku pre slovenskú Akreditačnú komisiu neprijatel’ná. Zároveň bolo zámerom využit' systém mobility pedagógov v rámci programu Erasmus+, ktorý by mohol slúžit' ako podpora projektu KAAT.

V priebehu roka 2018 sa situácia na Slovensku zásadne zmenila. Ministerstvo školstva, vedy, výskumu a športu Slovenskej republiky (MŠVVaŠ) pripravilo nový zákon č. 269/2018 Z. z o zabezpečení kvality vysokoškolského vzdelávania, ktorý dopíňa zákon o vysokých školách a Slovenská národná rada ho prijala a schválila. V roku 2018 však bol vysokoškolský zmenený ešte raz a to zákonom č. 270/2018 Z.z. Najdôležitejšie časti, ktoré opisujú nový spôsob akreditačného procesu nadobudli účinnost' 1 . septembra 2018. Zákonom o zabezpečovaní kvality vzdelávania bola zriadená nová slovenská Akreditačná agentúra, namiesto Akreditačnej komisie, ktorá existovala predtým a táto nová agentúra dostala úlohu vytvorit' štandardy pre slovenský univerzitný systém akreditácie do konca júna 2019. Po tomto termíne začal proces pripomienkovania štandardov univerzitami a ministerstvom. V súčasnosti (jún 2020) ešte stále nie je jasné, kedy nové štandardy začnú pre akreditačný proces platit'. To však nie je jediný problém. Súčasne s vyššie uvedeným procesom sa začala vytvárat' vyhláška MŠVVaŠ č. 244/2019 Z. z. o sústave študijných odborov Slovenskej republiky, ktorá nadobudla účinnost' 1. septembra 2019.

Koncom roka 2018 a začiatkom roka 2019, kedy vlastne nikto nevedel ako bude nový akreditačný proces vyzerat', sme začali vyvíjat' alternatívne riešenia, pretože sme si neboli istí, či je možné v rámci nedokončeného legislatívneho rámca pokračovat' $\mathrm{v}$ akreditácii, tak aby bol tento proces ukončený $\mathrm{v}$ termínoch stanovených projektom KAAT. Zvážili sme všetky možnosti, ako by bolo možné študijný program realizovat'. Po odbornej diskusii sme iniciovali spoluprácu s riaditel'kou Ústavu celoživotného 
vzdelávania Žilinskej univerzity v Žiline a na jej odporúčanie sme sa rozhodli akreditovat' ITAA ako program celoživotného vzdelávania. Podkladom pre naše rozhodnutie bol dokument vydaný MŠVVaŠ s názvom: Referenčná správa slovenských kvalifikačných rámcov k európskemu kvalifikačnému rámcu 2017, kde bola definovaná schéma - Štruktúra SKKR (pozri obr. 1). Z uvedenej schémy je zrejmé, že študenti môžu získat’ vysokoškolské vzdelanie aj prostredníctvom systému a programov celoživotného vzdelávania. Po diskusii na MŠVVaŠ sme sa rozhodli vytvorit’ a akreditovat' ITAA uvedeným spôsobom.

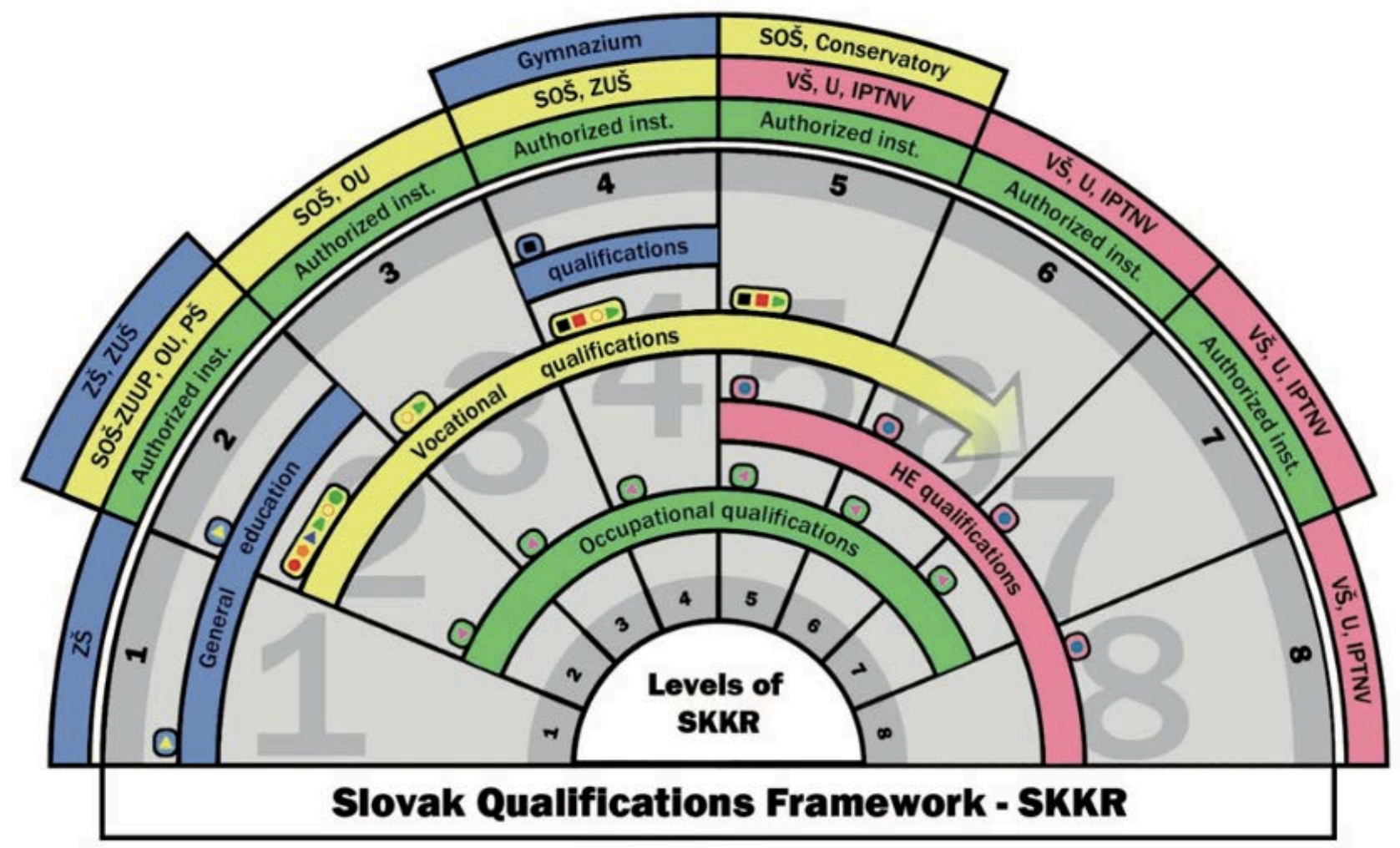

Obr. 1 Slovenský kvalifikačný rámec SKKR (Zdroj: Pathóová et. al., 2017)

Ďalším zákonom, ktorý mal podporovat’ akreditačný proces ITAA v rámci celoživotného vzdelávania bol návrh zákona, ktorým sa mal menit’ a dopĺňat’ zákon č. 568/2009 Z. z. o celoživotnom vzdelávaní v znení neskorších predpisov. Tento návrh bol v roku 2018 a 2019 v legislatívnom procese. Podl'a článku 2 ods. 4 až 6 uvedeného návrhu zákona je d’alšie vzdelávanie alebo celoživotné vzdelávanie neformálnym vzdelávaním, ktoré sa uskutočňuje vo vzdelávacích inštitúciách d’alšieho vzdelávania (d'alej len „Vzdelávacia inštitúcia“) a nadväzuje na školské vzdelávanie. Ďalšie vzdelávanie umožňuje získat' kvalifikáciu zodpovedajúcu relevantnej úrovni slovenského kvalifikačného rámca, doplnit', rozšírit' alebo prehĺbit' kvalifikáciu získanú formálnym vzdelaním alebo uspokojit’ záujmy a získat' schopnost' podiel’at' sa na živote občianskej spoločnosti. Úspešným ukončením d'alšieho vzdelávania je získaná odborná kvalifikácia a primeraná úroveň kvalifikácie podl’a slovenského kvalifikačného rámca. Ďalšie vzdelávanie sa uskutočňuje v štátnom jazyku a v závislosti od záujmu účastníkov o d'alšie vzdelávanie a možnosti vzdelávacích inštitúcií aj v inom jazyku ako je štátny jazyk. Uvedený návrh zákona však nebol schválený, pretože bývalá ministerka školstva, vedy, výskumu a športu ho v roku 2019 zastavila tesne pred predložením do Národnej rady SR (parlamentu). V súčasnosti sa však situácia na ministerstve školstva zmenila. Po vol'bách do Slovenskej národnej rady (parlamentu) na jar roku 2020 sú priority vlády a ministra školstva odlišné. Vo vládnom programovom vyhlásení sa okrem iného uvádza, že bude podporovat' rozširovanie realizácie študijných programov v cudzích jazykoch, podporovat' odstraňovanie prekážok pri realizácii interdisciplinárnych študijných programov a spoločných študijných programov medzi domácimi a zahraničnými univerzitami. Zdôraznenie dôležitosti interdisciplinarity by mohlo riešit’ 
aj jeden z d'alších problémov, ktoré je potrebné riešit', pretože riešitel'om projektu KAAT je Fakulta prevádzky a ekonomiky dopravy a spojov, ktorá je zameraná prevažne na dopravu, ekonomiku a manažment a v rámci UNIZA sú za študijné programy v oblasti IT zodpovedné iné fakulty. $\mathrm{S}$ súčasnosti nie je možné vytvorit' nový, podobný, študijný program z oblasti IT bez súhlasu dekanov týchto fakúlt a rektora. V súčasnom konkurenčnom prostredí, nielen na celoslovenskom trhu, ale aj medzi fakultami jednej univerzity vzájomne, to tiež nie je jednoduché.

Ďalším pozitívom programového vyhlásenia vlády vo vzt'ahu k zámerom projektu KAAT je podpora systematického preskúmania systému študijných odborov tak, aby opisy študijných odborov brali do úvahy najnovšie poznatky a vývojové trendy v príslušnej oblasti vedomostí a vychádzali z koncepcie zameranej na výsledky vzdelávania, odkazy na praktické požiadavky a vnútroštátny kvalifikačný rámec zahŕňajúci profesijné komory a potenciálnych zamestnávatel’ov. Vláda v oblasti celoživotného vzdelávania pripravuje novú legislatívu (zákon) o d’alšom vzdelávaní, celoživotnom vzdelávaní a uznávaní výsledkov d’alšieho vzdelávania, ktorý by mal zahŕňat' systematické zmeny v oblasti d’alšieho vzdelávania zamerané na zvyšovanie jeho kvality, ako aj zvyšovanie kvality vzdelávania, účast' dospelých na d'alšom vzdelávaní a možnost' získania kvalifikácie $v$ d'alšom vzdelávaní. Tým vytvára podmienky pre fungujúci systém uznávania kvalifikácií. Zároveň sa zaviazala podporovat' prostredie na uznávanie výsledkov neformálneho vzdelávania prostredníctvom národného kvalifikačného rámca vrátane zmien a doplnení príslušných právnych predpisov a zabezpečit' pravidelné monitorovanie zmien a rozvoja zručností v 21. storočí s ciel'om lepšie sa zamerat' na učebné osnovy d'alšieho vzdelávania. To je plne v súlade so stratégiou a ciel'mi projektu KAAT. Preto veríme v úspešný koniec akreditačného procesu v rámci systému celoživotného vzdelávania.

\section{3 Zlepšenie univerzitných študijných programov a odbornej prípravy}

V rámci WP4 - Zlepšenie univerzitných študijných programov a odbornej prípravy je projekt zameraný na inováciu a aktualizáciu univerzitných študijných programov a školení pre dospelých. Partneri preskúmali učebné osnovy siedmych existujúcich študijných programov a troch školení zameraných na špecializáciu a zvyšovanie vedomostí na základe výsledkov WP1 a WP2. Ako výstup tohto WP 4 UNIZA revidovala svoje dva existujúce bakalárske študijné programy Letecká doprava a Profesionálny pilot, kde namiesto ekonomických predmetov boli pridané dva nové predmety - Komunikačné systémy v leteckej doprave a Počítačové simulácie $\mathrm{v}$ leteckej doprave. Zameranie projektu zdôrazňuje aj dôležitost' duálneho vzdelávania, čo má Katedra leteckej dopravy zabezpečené prostredníctvom spolupráce s viacerými leteckými podnikmi ako napr. Go2Sky, AirExplore, Letisko M.R. Štefánika, Letisko Žilina, Letové prevádzkové služby SR š.p. a pod. Zároveň má aj skúsenosti s double degree študijnými programami. V súčasnosti máme dlhoročnú spoluprácu s Ecole Nationale de l'Aviation Civile (ENAC) Toulouse a zúčastnili sme sa double degree magisterského programu ATL - Transatlantic dual master degree program in Transportation and Logistics Systems.

\section{4 Metodika pre sektorový kvalifikačný rámec a uznávania predchádzajúceho vzdelania a pracovných skúseností v letectve}

V rámci WP5 -partneri projektu vypracovali metodiku pre sektorový kvalifikačný rámec a uznávanie predchádzajúceho vzdelania a pracovných skúseností v letectve ako aj najlepšie postupy („,best practices“) pre odvetvovú kvalifikáciu, čo znamená metodiku rozpoznávania zručností a kompetencí študentov pred plánovaním ich d’alšieho vzdelávania. To umožní nastavit’ doplňujúce vzdelávanie a jeho obsah priamo pre potreby študenta alebo požiadavky z priemyslu. 


\section{ZÁVER}

V súčasnosti je projekt v poslednom roku riešenia. Je možné konštatovat', že všetky zatial' nastolené problémy a vytýčené úlohy sme splnili tak ako je to uvedené v častiach 2.1 - 2.4 tohto článku. Je pravdou, že najväčším a do dnešného dňa ešte stále nedoriešeným problémom je úspešné akreditovanie nového študijného programu ITAA na Slovensku. Tento problém riešia ale aj d'alší traja partneri- University of Zagreb, University of Strausbourg a University of Lisbon. Napriek tomu je možné hodnotit' dosiahnuté výsledky partnermi ako vel'mi dobré, a preto všetci partneri priebežne zverejňujú informácie o projekte ako aj jeho výsledkoch, či už v odborných publikáciách alebo na webových stránkach a sociálnych siet’ach. V rámci rôznych aktivít zoznamujú pedagogickú a odbornú verejnost’ so závermi, správami a svojimi skúsenost’ami na medzinárodných vedeckých konferenciách a workshopoch. Na Slovensku bol zorganizovaný seminár „Vzdelávanie expertov v oblasti vodnej a leteckej dopravy“ pod záštitou Ministerstva dopravy a výstavby SR, ktorého závery boli podobné ako sú výsledky KAAT. Členka projektového tímu KAAT z Katedry leteckej dopravy (UNIZA) je členkou Sektorovej rady pre dopravu, logistiku a poštové služby, ktorá je zodpovedná za projekt Slovenskej sústavy povolaní, Národnej klasifikácie zamestnanosti SK ISCO-08 a Národného kvalifikačného rámca. V rámci tohto konceptu je preukázatel'né, že závery Projektu KAAT sú pre civilné letectvo SR prospešné a po úpravách aplikovatel'né aj v iných oblastiach dopravy.

Poslednou a asi najdôležitejšou pridanou hodnotou projektu je vytvorenie Európskej siete pre výcvik a vzdelávanie v oblasti letectva (ENATE), ktorá bude pokračovaním vzájomne dobrej spolupráce v projekte KAAT a zároveň zabezpečí udržatel'nost' projektu. Nové spoločné medzinárodné a multidisciplinárne študijné programy zaist'ujú medzinárodný rozmer leteckého vzdelávania a ovplyvňujú aj medzinárodnú zamestnanost', najmä v krajinách zúčastňujúcich sa na projekte. Študijné programy vypracované na základe vedeckých výsledkov projektu KAAT a ENATE budú zdiel'at’ a integrovat' osvedčené postupy a nové aktuálne predmety do vzdelávacích programov.

\section{Pod'akovanie}

Článok je publikovaný ako jeden z výstupov projektu KAAT - Knowledge Alliance in Air Transport je ERASMUS+, 588060-EPP-1-2017-1-RO-EPPKA2-KA.

\section{Literatúra}

Európska Komisia. 2009. Európsky kvalifikačný rámec pre celoživotné vzdelávanie (EKR), ISBN 978-9279-08489-8, doi 10.2766/28316

Fondová I, et. all. 2013. Metodika na tvorbu Národného kvalifikačného rámca v Slovenskej republike, Bratislava, ŠIOV 2013

Národná rada Slovenskej republiky. 2004. Zákon č. 5/2004 Z.z. o službách zamestnanosti v znení neskorších predpisov.

Národná rada Slovenskej republiky. 2009. Zákon č. 568/2009 Z.z. o celoživotnom vzdelávaní a o zmene a doplnení niektorých zákonov.

Národná rada Slovenskej republiky. 2018. Zákon č. $269 / 2018$ Z. Z. o zabezpečovaní kvality vysokoškolského vzdelávania s účinnost’ou 1. septembra 2018.

Národná rada Slovenskej republiky. 2018. Zákon č. 270/2018 ktorým sa mení a dopĺňa zákon č. 131/2002 Z. z. o vysokých školách a o zmene a doplnení niektorých zákonov v znení neskorších predpisov a ktorým sa menia a dopíňajú niektoré zákony s účinnost’ou 1. septembra 2018. 
MŠVVaŠ SR. 2019. Vyhláška MŠVVaŠ SR č. 123/2019 Z. z. o kreditovom systéme štúdia s účinnost'ou od 1. septembra 2019.

MŠVVaŠ SR. 2019. Vyhláška MŠVVaŠ č. 244/2019 Z. z. o sústave študijných odborov Slovenskej republiky, ktorá nadobudla účinnost' 1. septembra 2019.

Pathóová, I., Gállová, L., Junášková, A. 2017. Referencing report of the Slovak qualifications framework to the European qualifications framework, Bratislava, ŠIOV, ISBN 978-80-89247-62-2, 